Wandering Peoples 
A book in the series

Latin America Otherwise: Languages, Empires, Nations

Series editors:

Walter D. Mignolo, Duke University

Irene Silverblatt, Duke University

Sonia Saldívar-Hull, University of Texas, San Antonio 


\section{Wandering Peoples}

Colonialism, Ethnic Spaces, and

Ecological Frontiers in Northwestern Mexico, I700-I850

Cynthia Radding

Duke University Press Durham and London 1997 
(C) 1997 Duke University Press

All rights reserved

Printed in the United States of America on acid-free paper $\circledast$

Typeset in Joanna by Tseng Information Systems, Inc.

Library of Congress Cataloging-in-Publication Data appear on the last printed page of this book. 
To Benjamin Irving Radding and Dorothy Lowman Radding 
